\title{
Wpływ rezerw na zobowiązania długoterminowe w kształtowaniu polityki dywidendy przez publiczne spółki akcyjne
}

https://doi.org/10.33141/po.2005.06.09

Przegląd Organizacji, Nr 6 (785), 2005, ss. 38-41 www.przegladorganizacji.pl

Agnieszka Natasza Duraj Towarzystwo Naukowe Organizacji i Kierownictwa (TNOiK)

\section{Wstęp}

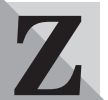

asadniczym celem opracowania jest przedstawienie roli i znaczenia tworzenia rezerw na zobowiązania długoterminowe w kształtowaniu polityki dywidendy przez publiczne spółki akcyjne. Realizacja tego celu oparta została na weryfikacji empirycznej hipotezy badawczej stanowiącej, że wzrostowi rezerw na zobowiązania towarzyszy polityka malejących wypłat dywidendy w publicznych spółkach akcyjnych. Bezpośrednią przyczyną podjęcia badań nad wpływem rezerw na zobowiązania długoterminowe na politykę dywidend jest brak pełniejszych opracowań i szerszych badań empirycznych nad tym problemem.

Polityka dywidend jest bardzo istotnym czynnikiem wzrostu wartości przedsiębiorstwa i bez wątpienia rezerwy na zobowiązania mogą wywierać na nią ważny wpływ. Należy stwierdzić, że tak sformułowane twierdzenie o wpływie rezerw na zobowiązania na politykę dywidendy może służyć do pełniejszego wyjaśnienia czynników kształtujących tę politykę. Kwestie te w sposób bezpośredni wiążą się z kształtowaniem struktury kapitału i wartości rynkowej przedsiębiorstwa. Polskie publiczne spółki akcyjne, w znakomitej większości, preferowały tworzenie rezerw na zobowiązania niż wypłatę dywidendy. Rezerwy na zobowiązania, jak dowiodło badanie sprawozdań finansowych 237 spółek akcyjnych notowanych na Giełdzie Papierów Wartościowych w Warszawie SA w latach 1997-2003, działających na rynku podstawowym, równoległym i wolnym, były tworzone głównie na odroczony podatek dochodowy, natomiast relatywnie mniej rezerw tworzono w badanych spółkach na świadczenia emerytalne i podobne.

\section{Tworzenie rezerw na zobowiązania i ich wpływ na podział wyniku finansowego netto}

W ogólnym znaczeniu termin „rezerwa” jest rozumiany jako specjalny fundusz, tworzony $\mathrm{w}$ ściśle określonym celu ${ }^{1}$. W literaturze anglojęzycznej rezerwy uważane są za celowo przyznane fundusze pochodzące z zysku zatrzymanego ${ }^{2}$.

Rezerwy na zobowiązania (provisions) w piśmiennictwie brytyjskim utożsamiane są z obecnym lub do- mniemanym zobowiązaniem przedsiębiorstwa do transferu korzyści ekonomicznych, będących rezultatem minionych zdarzeń, które mogą być w sposób wiarygodny oszacowane ${ }^{3)}$, jak również ze specyficznymi zobowiązaniami o niepewnym terminie lub kwocie poniesienia, stanowiącymi prawdopodobny przyszły wypływ środków pieniężnych z przedsiębiorstwa ${ }^{4}$. Podobne ujęcie odnaleźć można w standardzie FRS 12 „Provisions, Contingent Liabilities and Contingent Assets”, zawierającym m.in. sposoby uznawania rezerw oraz ich szacowania ${ }^{5}$, jak również sposoby zapobiegania manipulowaniu zyskiem ${ }^{6}$. Zbliżone ujęcie terminu „rezerwa” odnaleźć można w literaturze amerykańskiej. Zdaniem H.M. Smith rezerwy na zobowiązania (reserves) uważane są za pewien rodzaj zobowiązań firmy, powstających w wyniku rozdzielenia nadwyżki pieniężnej przedsiębiorstwa, przy czym winne być one rozwiązane wówczas, gdy powód, dla którego zostały utworzone przestał istniećc ${ }^{7}$. Tego rodzaju pogląd jest nadal aktualny nie tylko w teorii, lecz i praktyce tworzenia i uwalniania rezerw. Wystarczy tutaj przywołać pogląd E. Walińskiej, że w przypadku rozwiązania rezerwy należy rozpatrzyć dwa przypadki: rezerwy wykorzystanej oraz nie wykorzystanej ${ }^{8}$. Rezerwa winna być wykorzystana jedynie na cele, na jakie została utworzona. Przy ustaniu warunków wpływających na konieczność dalszego istnienia rezerwy należy ją rozwiązać w ciężar wyniku finansowego danego okresu. Powstanie zobowiązania, na które uprzednio utworzono rezerwę, zmniejsza rezerwę ${ }^{9}$. Rozwiązanie nie wykorzystanych rezerw, w przypadku zmniejszenia lub ustania ryzyka uzasadniającego ich utworzenie, zwiększa na dzień, na który okazały się zbędne pozostałe przychody operacyjne, przychody finansowe lub zyski nadzwyczajne ${ }^{10)}$.

Zdaniem E. Walińskiej, rezerwy na zobowiązania mają na celu urealnienie wartości zadłużenia przedsiębiorstw, co więcej, wiążą się one z jego przyszłymi wydatkami, które są na dzień bilansowy na tyle prawdopodobne, że zostały wykazane w bilansie, a nie ujęte jako zobowiazzania warunkowe ${ }^{11)}$. Utworzenie rezerw, jak dowodzi M. Gmytrasiewicz, oznacza jednocześnie obciążenie bieżących kosztów działalności i strat przedsiębiorstwa lub zmniejszenie zysku do podziału. Pozwala to zatem na wygospodarowanie aktywów przypisanych tym rezerwom w drodze zmniej- 
szenia wyniku finansowego lub wykorzystania nie podzielonych zysków z lat ubiegłych ${ }^{12}$.

\section{Wypłata dywidendy a wynik finansowy netto}

statnia nowelizacja kodeksu spółek handlowych wprowadziła istotne zmiany dotyczące wypłaty dywidendy w spółkach akcyjnych. Zgodnie z postanowieniami kodeksu spółek handlowych, wysokość kwoty przeznaczonej do podziału między akcjonariuszy stanowi sumę zysku netto za ostatni rok obrotowy, ujętego w zatwierdzonym przez biegłego rewidenta sprawozdaniu finansowym oraz zysków nie podzielonych z lat ubiegłych. Do uzyskanej wartości należy dodać kwotę przeniesioną z utworzonego z zysku kapitału zapasowego, przeznaczonego na wypłatę dywidendy oraz kwotę przeniesioną $\mathrm{z}$ utworzonego z zysku kapitału rezerwowego, przeznaczonego na wypłatę dywidendy. Następnie od sumy tej winna zostać odjęta wartość akcji własnych, jak również kwota zaliczki na dywidendę. W przypadku istnienia nie pokrytych strat z lat ubiegłych, ich wartość pomniejsza również wartość kwoty przeznaczonej do podziału między akcjonariuszy. Obniżana jest ona także przez kwotę, która zgodnie z ustawą lub statutem spółki winna być przeznaczona z zysku netto za ostatni rok obrotowy na kapitał zapasowy (co najmniej 8\%, dopóki kapitał zapasowy nie osiągnie $1 / 3$ kapitału zakładowego) oraz przez kwotę, która zgodnie z ustawa lub statutem spółki winna być przeznaczona z zysku netto za ostatni rok obrotowy na kapitał rezerwowy.

Powyższą procedurę obliczeniową można zapisać za pomocą następującego wzoru:

$\mathrm{K}_{\mathrm{dpa}}=\mathrm{Z}_{\mathrm{n}}+\mathrm{Z}_{\text {niepodz }}+\mathrm{K}_{\mathrm{kz}}+\mathrm{K}_{\mathrm{kr}}-\mathrm{A}_{\mathrm{wl}}-\mathrm{K}_{\mathrm{nkz}}-\mathrm{K}_{\mathrm{nkr}}-\mathrm{S}_{\mathrm{tr}}-\mathrm{Z}_{\mathrm{nd}}$

gdzie:

$\mathrm{Z}_{\mathrm{n}}$ - zysk netto za ostatni rok obrotowy, ujęty w zatwierdzonym przez biegłego rewidenta sprawozdaniu finansowym,

$\mathrm{Z}_{\text {niepodz }}$ - zyski nie podzielone $\mathrm{z}$ lat ubiegłych,

$\mathrm{K}_{\mathrm{kz}}^{\text {niepodz }}$-kwota przeniesiona $\mathrm{z}$ utworzonego z zysku kapitału zapasowego, przeznaczonego na wypłatę dywidendy,

$\mathrm{K}_{\mathrm{kr}}$ - kwota przeniesiona $\mathrm{z}$ utworzonego z zysku kapitału rezerwowego, przeznaczonego na wypłatę dywidendy,

$\mathrm{A}_{\mathrm{wf}}$ - akcje własne nabyte przez spółkę (i przeznaczone do umorzenia),

$\mathrm{K}_{\mathrm{nkz}}$ - kwota, która zgodnie $\mathrm{z}$ ustawą lub statutem spółki winna być przeznaczona z zysku netto za ostatni rok obrotowy na kapitał zapasowy (co najmniej 8\%, dopóki kapitał zapasowy nie osiągnie $1 / 3$ kapitału zakładowego),

$\mathrm{K}_{\mathrm{nkr}}$ - kwota, która zgodnie z ustawą lub statutem spółki winna być przeznaczona z zysku netto za ostatni rok obrotowy na kapitał rezerwowy,

$\mathrm{S}_{\mathrm{tr}}$ - nie pokryte straty z lat ubiegłych,

$\mathrm{Z}_{\mathrm{nd}}$ - kwota zaliczki na dywidendę.

Należy podkreślić, że walne zgromadzenie może swobodnie dysponować kapitałem zapasowym w części przekraczającej 1/3 kwoty kapitału zakładowego, stąd nadwyżka kapitału zapasowego ponad obowiązkowe minimum może powiększać kwotę dopuszczal- nej dywidendy w spółce akcyjnej (o ile jej statut nie stanowi inaczej).

Zaliczka na dywidendę może stanowić najwyżej połowę zysku osiągniętego od końca poprzedniego roku obrotowego, wykazanego w sprawozdaniu finansowym zbadanym przez biegłego rewidenta, powiększonego o kapitały rezerwowe utworzone z zysku, którymi w celu wypłaty zaliczek może dysponować zarząd oraz pomniejszonego o nie pokryte straty i akcje własne ${ }^{13)}$. Jej wypłata może nastąpić dopiero po zatwierdzeniu sprawozdania finansowego za poprzedni rok obrotowy. Nie może być ona sfinansowana kosztem nie wypłaconych zysków z poprzednich lat obrotowych ani kosztem kapitału zapasowego.

Należy zaznaczyć, że zysk netto może być przeznaczony na podwyższenie kapitału zakładowego, co wiąże się m.in. z problematyką zachowania przez spółki akcyjne odpowiedniego poziomu kapitału zakładowego, mającego na celu ochronę interesów wierzycieli ${ }^{14)}$, ujętego w Drugiej Dyrektywie ${ }^{15)}$, stąd wartość kwoty przeznaczonej do podziału między akcjonariuszy może być również pomniejszona o kwotę niezbędną do podwyższenia kapitału zakładowego spółki celem utrzymania go na wymaganym poziomie ${ }^{16)}$.

\section{Szacowanie wpływu tworzonych rezerw na zobowiązania na politykę wypłat dywidendy}

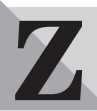

a cechę charakterystyczna rezerw na zobowiązania można uznać to, że niemożliwe jest poznanie rzeczywistych ich wielkości, a nawet terminu zapłaty w chwili ich tworzenia. Tym samym można mówić o ryzyku rezerw jako własnego i zarazem wewnętrznego źródła finansowania działalności. Możliwość ta wynika nie tylko stąd, że zasadniczym źródłem tworzenia rezerw na zobowiązania jest zysk netto, lecz także z potrzeb zapewnienia odpowiedniej sytuacji majątkowo-finansowej przedsiębiorstwa, zdolnej do wykreowania potencjału wzrostu wartości rynkowej przedsiębiorstwa.

Waga rezerw na zobowiązania kryje się w wypełnianiu przez nie wielu istotnych funkcji na rzecz zarówno samego przedsiębiorstwa, jego właścicieli, pracowników oraz państwa. Sa one zarówno rezerwami obligatoryjnymi, jak i fakultatywnymi. Rezerwy fakultatywne tworzą dla przedsiębiorstwa większe możliwości zarówno wykorzystania nadarzających się szans, jak i formułowania i realizacji specyficznych strategii działania.

Rezerwy na zobowiąania stanowia zarówno długo-, jak i krótkoterminowe źródło finansowania działalności gospodarczej przedsiębiorstwa, gdyż ujmowane sa w jej pasywach. A zatem tworzenie i rozwiazywanie rezerw na zobowiązania może w sposób istotny wpływać na strukturę pasywów przedsiębiorstwa. Co więcej, zmiana struktury pasywów może zostać spowodowana również wypłatą dywidendy, gdyż jej uchwalenie przez walne zgromadzenie jest równoznaczne $\mathrm{z}$ pojawieniem się $\mathrm{w}$ zobowiązaniach bieżących dodatkowej pozycji i ze zmiana struktury pasywów. W tym sensie można mówić, że zarówno wypłata dywidendy, przyjmująca zresztą bardzo zróżnicowane, a nie tylko pieniężne formy, jak i rezerwy na 
zobowiązania są instrumentami zarządzania strukturą zadłużenia przedsiębiorstwa.

Tworzenie rezerw na zobowiązania, jak i decyzję o wypłacie dywidendy można traktować jako działalność regulacyjną władz przedsiębiorstwa zmierzającą do skutecznego tworzenia i utrwalenia warunków wzrostu wartości rynkowej przedsiębiorstwa. Można przypuszczać, że niektóre publiczne spółki akcyjne będą bardziej skłonne wypłacać wyższą dywidendę celem pozyskania nowych akcjonariuszy czy utrzymania dotychczasowej struktury akcjonariatu, natomiast inne - tworzyć wyższe rezerwy na zobowiązania, mające na celu zapewnienie warunków pomyślnego funkcjonowania przedsiębiorstwa w długim okresie. Te dwa cele moga mieć nieraz charakter substytucyjny, co oznacza, że wzrostowi wypłaty dywidendy towarzyszy obniżenie kwoty rezerw na zobowiązania, zaś wzrostowi rezerw - obniżenie kwoty wypłacanej dywidendy lub nawet jej niewypłacenie. Należy bowiem podkreślić, że zarówno tworzenie rezerw na zobowiązania, jak i wypłata dywidendy, wiążą się z przeznaczeniem na ten cel przez przedsiębiorstwo części zysku netto wygospodarowanego w danym roku obrotowym. Można zatem domniemywać, że zarząd spółki będzie traktował decyzje o wypłacie dywidendy oraz o utworzeniu rezerw jako swoistego rodzaju łamigłówkę, gdyż przeznaczenie większej części wyniku finansowego na dywidendę będzie mogło być równoznaczne z koniecznością ograniczenia kwoty rezerw na zobowiązania i odwrotnie.

\section{Opis metody badawczej}

W celu zdiagnozowania wpływu rezerw na zobowiązania na politykę wypłat dywidendy publicznych spółek akcyjnych dokonano analizy sprawozdań finansowych (bilansu, skąd pochodziły dane dotyczace kwot tworzonych przez spółki rezerw na zobowiązania oraz rachunku przepływu środków pieniężnych, niezbędnego do ujawnienia kwot wypłacanych dywidend) 237 spółek akcyjnych notowanych na Giełdzie Papierów Wartościowych w Warszawie w latach 1997-2003 (na wszystkich jej rynkach: podstawowym, równoległym i wolnym oraz na rynku pozagiełdowym - CeTO). Na podstawie sprawozdań tych spółek wyodrębniono spółki, które we wszystkich latach analizowanego okresu wypłacały dywidendę oraz tworzyły rezerwy na zobowiązania ${ }^{17}$. Spośród 237 spółek jedynie sześć $\mathrm{z}$ nich $\mathrm{w}$ całym badanym okresie tworzyło zarówno rezerwy na zobowiązania, jak i dokonywało wypłat dywidendy. Spółkami tymi były: PKN Orlen SA, Dębica SA, Permedia SA, Jutrzenka SA, Świecie SA oraz Stalprofil SA. Pozostałe spółki poddane badaniu (za wyjątkiem spółek Efekt SA i Talex $\mathrm{SA}^{18)}$ ) wypłacały dywidendę okazjonalnie lub nie wypłacały jej wcale ${ }^{19}$.

Po dokonaniu wyboru spółek dokonano oszacowania wartości współczynników korelacji $(\rho)$ dla zależności między kwotą utworzonych rezerw na zobowiązania a kwotą wypłaconej dywidendy, a następnie przeprowadzono badanie istotności uzyskanych współczynników korelacji z wykorzystaniem statystyki t-Studenta. W tym celu sprawdzone zostało przypuszczenie, że zmienne te są nieskorelowane, a zatem że współczynnik korelacji $\rho$ jest równy zeru $\rho=0\left(\mathrm{H}_{0}\right)$ wobec hipotezy alternatywnej stanowiącej, że współczynnik korelacji jest istotnie różny od zera $\left(\mathrm{H}_{1}\right)$.

\section{Weryfikacja hipotezy badawczej - badanie współczynników korelacji oraz ich istotności}

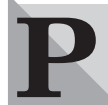

rzeprowadzona analiza współczynników korelacji dla zależności występującej między rezerwami na zobowiąania a wypłata dywidendy dowiodła, że w jednej spośród sześciu badanych spółek wystąpiła bardzo silna zależność między analizowanymi zmiennymi (Permedia SA), w dwóch spółkach (Jutrzenka SA, Stalprofil SA) - zależność znacząca, w jednej umiarkowana (PKN Orlen SA) oraz niska (Dębica SA), natomiast w spółce Świecie, ze względu na niską wartość współczynnika korelacji, nie stwierdzono występowania związku między rezerwami na zobowiązania a wypłatą dywidendy (zob. tabela 1).

Tab. 1. Wartości uzyskanych współczynników korelacji dla zależności występującej między rezerwami na zobowiązania a wypłatą dywidendy $w$ analizowanych spółkach

\begin{tabular}{|r|c|c|c|c|c|c|}
\hline Spółka & Permedia & Jutrzenka & Stalprofil & PKN Orlen & Dębica & Świecie \\
\hline wartość współczynnika korelacji & $\mathbf{0 , 9 2 1 0}$ & $\mathbf{- 0 , 7 4 6 3}$ & $\mathbf{0 , 7 1 1 6}$ & $\mathbf{0 , 5 5 7 3}$ & $\mathbf{- 0 , 2 6 5 2}$ & $\mathbf{- 0 , 0 9 3 3}$ \\
\hline
\end{tabular}

Źródło: opracowanie własne.

Tab. 2. Zestawienie wyników badania istotności współczynników korelacji dla zależności między rezerwami na zobowiązania a wypłatą dywidendy dla różnych poziomów istotności

\begin{tabular}{|c|c|c|c|c|c|c|c|c|c|c|c|}
\hline & $\mathbf{t}$ & $\alpha=0,1$ & wniosek & $\alpha=0,05$ & wniosek & $\alpha=0,02$ & wniosek & $\alpha=0,01$ & wniosek & $\alpha=0,001$ & wniosek \\
\hline Permedia & 5,29 & \multirow{6}{*}{2,015} & $\rho \neq 0$ & \multirow{6}{*}{2,571} & $\rho \neq 0$ & \multirow{6}{*}{3,365} & $\rho \neq 0$ & \multirow{6}{*}{4,032} & $\rho \neq 0$ & \multirow{6}{*}{6,859} & $\rho=0$ \\
\hline Jutrzenka & 2,51 & & $\rho \neq 0$ & & $\rho=0$ & & $\rho=0$ & & $\rho=0$ & & $\rho=0$ \\
\hline Stalprofil & 2,26 & & $\rho \neq 0$ & & $\rho=0$ & & $\rho=0$ & & $\rho=0$ & & $\rho=0$ \\
\hline PKN Orlen & 1,50 & & $\rho=0$ & & $\rho=0$ & & $\rho=0$ & & $\rho=0$ & & $\rho=0$ \\
\hline Dębica & 0,62 & & $\rho=0$ & & $\rho=0$ & & $\rho=0$ & & $\rho=0$ & & $\rho=0$ \\
\hline Świecie & 0,21 & & $\rho=0$ & & $\rho=0$ & & $\rho=0$ & & $\rho=0$ & & $\rho=0$ \\
\hline
\end{tabular}

Źródło: opracowanie własne. 
Przeprowadzone badania istotności współczynników korelacji dla zależności występującej między rezerwami na zobowiązania a wypłatą dywidendy dla różnych poziomów istotności $\alpha$ wynoszących 0,$1 ; 0,05$; 0,$02 ; 0,01$ oraz 0,001 oraz dla 5 stopni swobody (ze względu na siedmioletni okres badania) wskazują, że w trzech spółkach otrzymane współczynniki korelacji dla analizowanej zależności były istotne (zob. tabela 2 ).

Należy zatem stwierdzić, że w spółkach Permedia SA (przy poziomie istotności $\alpha=0,1 ; \alpha=0,05 ; \alpha=0,02$ oraz $\alpha=0,01$ ) oraz Stalprofil SA (przy poziomie istotności $\alpha=0,1$ ) wzrost kwoty rezerw na zobowiązania wpływał na wzrost kwoty wypłacanej dywidendy. Natomiast w spółce Jutrzenka SA wzrost kwoty tworzonych rezerw wpływał na spadek kwoty wypłacanej dywidendy (dla poziomu istotności $\alpha=0,1$ ). W pozostałych spółkach nie ma podstaw do odrzucenia hipotezy zerowej stwierdzającej brak skorelowania rezerw na zobowiązania $\mathrm{z}$ wypłatą dywidendy dokonywaną przez te spółki.

\section{Zakończenie}

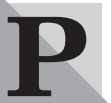
ubliczne spółki akcyjne dokonywały wypłaty dywidendy sporadycznie, a wiele $\mathrm{z}$ nich w całym badanym okresie nie dokonało jej wcale. Spośród 237 spółek poddanych badaniu jedynie osiem przez cały analizowany okres stosowało politykę stałych, corocznych wypłat dywidendy.

Jedynie tylko dla sześciu spółek akcyjnych udało zbadać się wpływ rezerw na zobowiązania na wypłatę dywidendy. Na podstawie przeprowadzonej analizy można stwierdzić, że w spółkach Permedia SA oraz Stalprofil SA wzrost kwoty rezerw na zobowiązania wpływał na wzrost kwoty wypłacanej dywidendy, natomiast w spółce Jutrzenka SA wzrost kwoty tworzonych rezerw wpływał na spadek kwoty wypłacanej dywidendy. W pozostałych trzech badanych spółkach (PKN Orlen SA, Dębica SA, Świecie SA) tworzenie rezerw na zobowiązania nie wywierało wpływu na politykę dywidendy stosowaną przez te przedsiębiorstwa.

Przedstawione rezultaty badań nie upoważniają do wyprowadzenia zdecydowanego wniosku o tym, że wzrostowi wypłaty dywidendy towarzyszy zmniejszenie kwoty zobowiązań na zobowiązania długoterminowe.

\section{dr Agnieszka Natasza Duraj Katedra Analizy i Strategii Przedsiębiorstwa Uniwersytetu Łódzkiego}

\section{PRZYPISY}

1) Reserves and Retained Income. Supplementary Statement No. 1, Committee on Concepts and Standards Underlying Corporate Financial Statements, American Accounting Association, Accounting Review, kwiecień 1951, vol. 26, s. 153 .

2) H.G. BROWN, Division of Retained Earnings to Reflect Business Needs, „Accounting Review”, kwiecień 1957, vol. 32 , s. 259 .

3) Provisions, Contingent Liabilities and Contingent Assets, „Management Accounting: Magazine for Chartered Management Accountants", październik 1997, vol. 75, s. 4.
4) Has the „Big Bath” Finally Sprung a Leak?, „Management Accounting: Magazine for Chartered Management Accountants", maj 1999, vol. 77, s. 5.

5) Exposure Draft on Amendment to FRSSE, „Management Accounting: Magazine for Chartered Management Accountants", wrzesień 1999, vol. 77, s. 42.

6) M. CASSIDY, K. WILD, The Devil is in the Detail, section: Provisions, „Management Accounting: Magazine for Chartered Management Accountants”, wrzesień 1999, vol. 77 , s. 32 .

7) H.M. SMITH, The Uses of Reserves on the Right - Hand Side of the Balance Sheet, „Accounting Review”, styczeń 1960, vol. 35, s. 100.

8) E. WALIŃSKA, Rezerwy w polskim prawie bilansowym, „Acta Universitatis Lodziensis”, „Folia Oeconomica” $159 / 2002$, s. $71-72$.

9) A. ROSINSSKA, M. RYTWIŃSKA, Rezerwa czy zobowiazanie warunkowe - prawidtowa kwalifikacja operacji gospodarczych, „SFK” nr 13 (415), 29 marca 2003 r., s. 47.

10) L. PONIATOWSKA, Klasyczne rezerwy rachunkowości $i$ bierne rozliczenia międzyokresowe, część II, „Monitor Rachunkowości i Finansów" nr 10/ 2004, s. 7.

11) E. WALIŃSKA, Rezerwy $w$ polskim prawie bilansowym, op.cit., s. 67.

12) M. GMYTRASIEWICZ, Rezerwy $w$ księgach rachunkowych. Tworzenie, wykorzystywanie, rozwiazywanie, Difin, Warszawa 2002, s. 10.

13) T. WAŚLICKI, Problemy zwiazane $z$ ewidencja zaliczek na dywidendę, „Monitor Rachunkowości i Finansów” nr $3 / 2004$, s. 21.

14) B.R. CHEFFINS, Company Law: Theory, Structure and Operation, Oxford 1997, s. 524-525.

15) Second Council Directive 77/91/EEC of 13 December 1976 on the Harmonization of European Company Law.

16) W ostatnich latach coraz częściej dyskutowany jest problem utrzymania odpowiedniej wartości kapitału zakładowego - zob. np. F. KUBLER, A Comparative Approach to Capital Maintenance: Germany, „European Business Law Review”, wrzesień/październik 2004, vol. 15, s. 10311036; J. SIMON, A Comparative Approach to Capital Maintenance: France, „European Business Law Review”, wrzesień/październik 2004, vol. 15, s. 1037-1044; H. MERKT, Creditor Protection and Capital Maintenance from a German Perspective, „European Business Law Review", wrzesień/październik 2004, vol. 15, s. 1045-1058; P. LEYETE, The Regime of Capital Maintenance Pertaining to Public Companies, Its Reform and Alternatives, „Business Law Review”, kwiecień 2004, vol. 25, s. 84-93 ASB Welcomes Proposals to Reform Capital Maintenance, „Accountancy”, lipiec 2004, vol. 134, s. 14.

17) Badaniem nie zostały objęte spółki należące do sektora bankowego oraz do sektora ubezpieczeń, jak również Narodowe Fundusze Inwestycyjne. Wybór takiej próby badawczej jest spowodowany zawężeniem prowadzonej analizy jedynie do przedsiębiorstw, natomiast w opracowaniu abstrahuje się od działania specyficznych jednostek, jakimi są banki, zakłady ubezpieczeń oraz NFI.

18) Spółki te - mimo dokonywania co roku wypłaty dywidendy - nie tworzyły we wszystkich latach badanego okresu rezerw na zobowiazania.

19) Niektóre spółki, jak np. Żywiec SA mimo prowadzenia przez wiele lat polityki corocznej wypłaty dywidendy, ze względu na poniesioną stratę netto $\mathrm{w}$ roku poprzednim nie mogły dokonać wypłaty dywidendy w roku nastepnym. W przypadku spółki Zywiec taka sytuacja miała miejsce w roku 2002 i była spowodowana poniesiona przez spółke stratą netto w roku 2001. Należy podkreślić, że spółka ta jako jedyne przedsiębiorstwo, poczawszy od roku 1991 prowadziła politykę corocznych wypłat dywidendy, co więcej politykę tę można określić jako politykę stałej lub wzrastającej kwoty dywidendy. 